\title{
Principles Detailed in the Quran, which Regulate the Lives of Muslim Women
}

\author{
Iyad Harafesheh \\ Market Street Muswellbrook, Australia \\ eyyad_jor@yahoo.com
}

Abstract: Women in Islam have always been an issue of contention especially in the modern society. As opposed to the modern society, Islam has maintained strict rules and roles in regards to women. Muslim women have to live the way they used to ages ago. In addition, the rights of women are restricted in women as opposed to men. The dramatic changes in the modern society are pushing the Muslim conservative rules and regulations to the corner. It is uncertain whether Muslims will be able to hold up on the strict rules and regulations. After all, it is becoming necessary for women to work to maintain their families better.

Keywords: Quran principle, Muslim women, Islamic rules, qawwamah.

\section{WOMEN IN ISLAM}

\section{INTRODUCTION}

Islam has a particular philosophy regarding the family rights of males and females. The religion does not advocate for similar freedoms and obligations for both genders in each case. Islam regards one group of right and obligations more suitable for males, while the other is more suitable for females. The Quran is the basis for these rights and protections, which are apparent for women. Hence, in Islam, women are governed by different principles from the Quran. Some of the principles regulate the lives of Muslim women (Tatar and Majid 19).

Although Islam takes females equal to males before God, they do not take pleasure in the same social equality, in the community. It is in a social framework that the overall underlying principle for women's lowliness to men, communicated in the Quran verses, which states "men have an advantage over the women" and "men are the protectors and maintainers of women" must be comprehended (Sidani 501). Associations amid males and females are directed by the principle of complementarily in place of fairness. In most Islamic communities, there prevails a differentiation of responsibilities forming a woman's place in the clandestine of the home (Sidani 501). On the contrary, the man's space is unrestricted in any way according to the Quran. As a result, women depend on males, and due to the dependence, the Quran validates that males should be in control of females at all times. A woman's duties are interpreted as becoming a mother and wife, while the man is expected to work and support the children and wife money-wise (Sidani 501).

Jurists have employed the superiority principle, qawwamah to rationalize several regulations of Islamic women freedoms, which can be evaluated under the rubric of fairness by law (Zayzafoon 213). Whereas the Shariah realizes a sovereign lawful personality for females, it fails to indicate any social, economic or political fairness for women. Islam does not restrict females from portraying their views on public matters, or from voting for persons contesting for official positions. The Quran does not outlaw women from implementing immediate political rule. However, according to the principle of qawwamah, females are lawfully ineligible from becoming high-ranking officials. According to the qawwamah principle, women in politics or the judiciary may be interpreted as exercising power over males (Zayzafoon 213). 
The Islamic rule forbids women from becoming a caliph, or imam. The law also prohibits women from becoming judges. The regulation of females from holding official positions is regarded to be partially founded on what is supposed to be Quranic prerequisites of the veil and gender isolation (Shipley 361). An often-quoted hadith is Prophet Mohammed quoted noting that persons that delegate their affairs to females will never be aware of opulence. On the foundation of the overall principle of qawwamah, and the particular principle from the Quran about testimonial knowledge, jurists regard a female's acknowledgment as imperfect. In social cases, a woman's evidence is significant for half that of a man. Women do not qualify to become witnesses in scandalous cases regardless of the number of female witnesses available. In a similar manner, as a universal principle, also in line with the particular Quranic rules from verses 4:11, as well as 4:176, is that women can only inherit half the same as men of the similar level of association to the departed (Shipley 361).

The region of family law provides another basis for evaluating principles detailed in the Quran restricting Muslim women. Marriage brings to light the restrictions on Islamic women. The Quran permits males to get married to four wives at the similar time, and the men have more freedoms to divorce any of the females as they wish through the one-sided negation. On the contrary, females are allowed to get a divorce merely through particular grounds. Females can merely ask for divorce by persuading a qadi to allow the divorce (Huq and Rashid 14). The strict regulations are because divorce is prohibited for Islamic women. The females are never allowed to marry men from any other religion. The Islamic rule asserts that Muslims should not indulge themselves with positions lesser to those of persons from different spiritualities. Contrary, the Quran clearly permits Muslim males to marry faithful females, referring to Christians, Jews and Sabians (Huq and Rashid 14).

Women in Islam are allowed to vocation, subject to particular circumstances. There are suggestions that women can work in the case of monetary need. The Quranic illustration of two women shepherd in Quran 28:23 support women vocation (Vassarotti 500). Islam realizes that the community requires females to work for the benefit of advancement. Women's freedoms to work are subject to particular circumstances. Conversely, the vocations do not mandate the woman to go against Islamic rule, like serve alcohol, and be considerate of the female's wellbeing. In case the job needs the female to leave her home, they should ensure modesty (Vassarotti 500). The Islamic rule is clear that even if women are working, they should also ensure they do their usual obligations like responsibilities to the family. However, the employment of females differs in Islamic rule. While they might seek medical treatment from males, it is opted that they get treatment from women. It is also opted that the female learning institutions hire females than males. Even when females are allowed to work and are informed, their vocations might in practice differ to males. For instance, in Egypt, females have restricted chances to work in the private sector as women are still supposed to consider their duties as wives and mothers first. This makes males to be perceived as more dependable in jobs compared to women (Vassarotti 500).

\section{HISTORICAL BACKGROUND}

The Quran was open to the prophet in a period of 23 years. The real meaning of its communication is to ascertain the oneness of God and the spiritual and ethical requirement of man to God. The requirement in ascertained through worship and compliance, and has eventual consequences thereafter due to God's word unique technique and expressiveness. In addition to the direction and lawful provisions, it provides guidance on how a family and the society should be (Sharify-funk and Haddad 45).

\section{IMMEDIATE AND LONGER TERM EFFECTS FOR WOMEN}

The Islamic understanding and consideration of womanhood derives from the holy Quran in the sense that the Holy Book stipulates what the women can do and what they cannot do. In a religious context, such considerations epitomize holiness and allegiance to the teachings of Allah. However, in practical realistic reality, these stipulations have results regarding the way women live. In the short-run, these consequences may not be 
witnessed further asserting the importance of these regulations. In essence, Islam is a religion that regulates the lives of women to an extent that women often play subservient roles to men. In that regard, Islam is similar to other religions because they all contemplate lesser roles for women (Vassarotti 500).

The Islamic religion and its relationship with the role of women offer moral checks and balances in addition to the balance of power and responsibility between males and females. In the intermediate moment, such a consideration is modest because it creates order and saves society from the consequences of the excesses of women in particular morality. From the dress code to mannerism, Islamic principles contemplate a modest as a woman whose objective is not only to please God, but also lives in harmony with society. These stipulations are acceptable in the society and are supported by the traditional roles of a woman, which include serving the husband and taking care of the children (Tatar and Majid 19).

The Islamic woman honors God and respects the man creating a system that resonates well with virtually all cultures. With the advent of westernization, Islam remains the only custodian of social order about the role of women. In accordance with the principles of Islam, there is no clash of roles among males and females regardless of the rampant changes in the world today. In addition, there are certain manners that are only tolerable among males, as opposed to females. In essence, these are realistic in the sense that they do not necessarily impinge on the rights of women, rather they protect the modesty and decency of the Muslim woman. The society remains a better place to live when women understand their roles, accept them and respect God and man (Vassarotti 500).

Conversely, the strict code of conduct, dressing and stipulation of women by Islamic religion is detrimental in the end because times are changing rapidly. What works today may not work tomorrow pushing the Islam religion conservative approach to the corner. The roles of women are changing fast and globally the attitude and understanding of women is changing. It may not be possible to constrain women in domestic chores anymore. Education has led to the transformation of kinds and perceptions heralding new perspectives of womanhood in the society. Therefore, it may be necessary to exercise restraint on the enforcement of strict Islamic principles regarding women (Sharify-funk and Haddad 45).

The needs of women change with their level of education and societal set up. The strict principles of Islam were operational during the past structures of society. Modern times have changed the way things work and insisting that women conduct themselves they way they did centuries back is not feasible. For instance, dress codes today emanate from weather patterns, nature of work or purpose, as opposed to the traditional society. Therefore, it is no longer possible to tell somebody how to dress in the present times. Other issues include marriage, family and child rearing. Some women may opt not to get married yet they may want to have children. Women refusing to get married appear as moral decay according to the Islamic principles, but this is far from the truth because certain lifestyles are needed because of changing structure of the modern society, thinking and attitude patterns. It may become necessary for Islam to accommodate some of these things because of the changing nature of the society (Tatar and Majid 19).

A woman playing subservient roles to men and only participating in domestic duties may no longer be sustainable in today's individualistic society. The high costs of living and scarce resources may necessitate women to go to work to supplement their husbands' income. The future is dim for the Islamic woman insisting on traditional attitudes and perceptions of society. In the end, practicing the Islamic principles about womanhood could be very difficult and harmful to Islamic women. Owing to the modern trends in the modern economy, society, politics and understanding, women may not thrive fruitfully if they fully adhere to Islamic principles not because the principles are bad but because they may not be practical in the changing dispensation. Strictly adhering to the established principles of Islam could have severe consequences on one hand or only be impossible on the other (Sharify-funk and Haddad 45). 
Principles Detailed in the Quran, which Regulate the Lives of Muslim Women

\section{CONCLUSION}

As a religion, Islam has specific principles that regulate the behavior, conduct and lives of Muslim women. These regulations emanate from the teachings of the Holy Quran. Among the most vital pillars of Islamic teachings, regarding women is the relationship between males and females. Women tend to play subservient roles to men and much of their role involves domestic duties. Women in Islam dress, in accordance to established customs where exposure of their body parts is against the law. Most of these regulations border on division of roles and the morality, decency and modesty of a woman. The controversy surrounding Islamic understanding about women is whether these principles are sustainable or unsustainable. The changing structure of society is a huge challenge to these principles of Muslim conduct. There could be challenges in the future regarding the sustainability and practicality of the Islamic principles of women. As time changes, it may be imperative for Muslim women to draw a line between religion and reality about the adherence to strict Islamic principles in the face of liberal social, political and economic structures of the modern world. The current changes in the world could be a real test for Islam as a religion.

\section{REFERENCES}

Huq, Samia; Rashid, Sabina Faiz. "Refashioning Islam: elite women and piety in Bangladesh." Contemporary Islam.2.1. (Mar 2008): 7-22. Print

Sharify-funk, Meena; Haddad, Munira Kassam. "Where Do Women 'Stand' In Islam? Negotiating Contemporary Muslim Prayer Leadership In North America." Feminist Review 102. (Nov 2012): 41-61. Print

Shipley, Heather. "Women Shaping Islam: Reading the Qur'an in Indonesia." Sociology of Religion.69.3. (Fall 2008): 360-362.Print

Sidani, Yusuf. "Women, work, and Islam in Arab societies." Women in Management Review. 20.7/8. (2005): 498-512. Print

Tatar, Azalina and Majid, Latifah Abdul. "Kefahaman Wanita Islam Kelas Menengah di Lembah Klang Terhadap Islam Liberal/The Understanding of Middle Class Muslim Women in the Klang Valley towards Liberal Islam." Islamiyyat. 34. (2012): 13-25. Print

Vassarotti, Therese. "Women And Fundamentalism In Islam And Catholicism: Negotiating Modernity In A Globalised World." The Australasian Catholic Record.88.4. (Oct 2011): 500-502. Print

Zayzafoon, Lamia Ben Youssef. "Teaching About Women and Islam in North Africa: Integrating Postcolonial Feminist Theory in the Classroom." Foreign Language Annals.44.1. (Spring 2011): 181-233. Print

Citation: Iyad Harafesheh. "Principles Detailed in the Quran, which Regulate the Lives of Muslim Women" American Research Journal of Humanities and Social Sciences, vol 4, no. 1, 2018, pp. 1-4.

Copyright (c) 2018 Iyad Harafesheh, This is an open access article distributed under the Creative Commons Attribution License, which permits unrestricted use, distribution, and reproduction in any medium, provided the original work is properly cited. 